\title{
Nexus of Political Connections with Green Finance and Financial Performance
}

\author{
Rabia Najaf*, Khakan Najaf \\ Taylor's University, No 1. Jalan Taylor's, 47500 Subang Jaya, Selangor, Malaysia
}

Received: 21/09/2020

Accepted: 23/11/2020

Published: 20/03/2021

\begin{abstract}
One of the most crucial aspects of the business environment is interaction with the government. Government entities have more chances to gain their gratifying targets for secular growth, monumental work, and sustainable development. We are trying to determine whether political connections are valuable for green corporate finance and corporate performance. Based on the prior literature, political ties have better sustainable development priorities and financial performance than non-politically connected firms. It is because they have sufficient resources to protect the natural environment, which eventually enhances financial performance. Our findings corroborate with the stewardship theory that states the empowered board is a better decision-maker. Our study has considerable implications for the research as it will enhance the knowledge about political ties.
\end{abstract}

Keywords: Government entities, Accusations, Gratifying targets

\section{Introduction}

The nexus among politician allies and corporations are known as well-defined phenomena all over the world. Most studies delineate that these connections are generally valuable to boost green finance and firm values $[8 ; 16]$. Political connections have a role in raising the interest of public opinion. This issue is significant as the shareholders have interest in listed firms and the relationship with the political ties may strengthen or prejudice the corporation growth. The political connetions association with green finance and corporate performance is imperative for the escalation of firms' goals. The government linked firms are known as the financial hub of all the markets $[2 ; 4 ; 10 ; 14$; $17 ; 21 ; 32]$. In this study, we examined the intervening effect of political ties on green investment of the firms, and the corporate performance. We provide a comprehensive look at the corporate political connections with respect to the prior literature. Following the prior premises $[15 ; 35 ; 49]$, we address a central research question: will a political connection strengthen the green finance and corporate performance?

In the context of green development, significance has been given to environmental responsibility from all the listed sectors; especially it is true in terms of industrial sectors [27]. World Health Organisation (WHO) and many other social service organisations have forced all listed firms to implement green investment strategies, with an exceptional increase in demand of stakeholders' environmental protection, meanwhile achieving corporate performance [20]. Political ties may significantly affect the firms' behavior and performance. Political connections are considered to be one

*Corresponding author: Rabia Najaf, Taylor's University, No 1. Jalan Taylor's, 47500 Subang Jaya, Selangor, Malaysia.Email: Rabianaajf@gmail.com of the most crucial resources for firms [13]. Thus, this study is focusing on the impact of political ties on corporate environmental performance. It is an important issue, as many studies are uncertain about the underlying relationship between them. Some studies argue that political connections foster environmental responsibility, and some assert that political ties hinder it [30], whereas others assert that politically connected companies tend to evade environmental regulations and have less environmental investment due to government asylum [50;51]. This contradiction of studies leads us to the following question: Do political connections strengthen or weaken corporate environmental performance?

Most of the studies documented that political associations are prevalent for firm performance $[2 ; 3 ; 10 ; 14$; 32). Importantly, politicians have close links with business through conferring favors such as privileges enshrined, contract rewards, and financial resources. The large corporations are interested in devoting their massive resources to the political system. It is because democracy ${ }^{2}$ is overgrowing, which has influenced corporate performance [18]. According to the resource dependency theory, external resources ultimately boost firm performance [3]. Mention previous studies prove that political connections are known as the significant avenues of burgeoning the corporation performance. Genuinely, these corporations are overhauling other firms due to their performance. A group of investors is unanimous in investing such sort of corporations. They are making a restricting plan and bring suable changes for the incredible development of the entity and renders different cautions to avoid the losses [42]. It is a suitable source to rein the risk of losing growth. Ultimately, the advantages ultimately can enhance corporation efficiency.

${ }^{2}$ A system of government by the whole population or all the eligible members of a state, typically through elected representatives. 
As discussed before, hundreds of companies hire legislative members to escalate their revenue streams and consolidate the business through external resources. In the corporate world, such connections are recognized by the name of assets of the company. Arguably, building political connections are valuable for the corporation because they are share market anticipates [41]. To give better insight into the nature of political connections and illuminate the significant root, it is essential to understand why and how political connections impact firm performance. Political connections left their spectrum on corporate performance [2]. To sum up, all these shreds of evidence prove that political connections have a positive and negative impact on firm performance.

The remainder of the paper is as follows. Section 2 reviews the literature. Section 3 elaborates the prior literature into the discussion, and section 4 concludes the study.

\section{Literature Review}

\subsection{Political connections and Green Finance}

A significant amount of the studies have supported the evidence of a positive association between political ties and green finance. David \& Sinclair-Desgagné (2010) [12] suggest that access to green investment can be achieved through political links. It is worth noting that the politically connected firms have easy access to the financial incentives which expand their environmental performance and facilitates to implementation of government environmental policies [44]. As per the resource dependence theory, Lin et al., (2015) [30] suggested that the politically connected firms are able to achieve more significant green finance due to the accessible resources. Following the same premises, Wang et al., (2018) [44] posited that the politically connected firms have a positive linkage with green finance. It is because the political connections are motivated to employ green practices and have received critical resources through political links. Thus, firms with political connections have better environmental performances.

In contrast, many studies have articulated that political linkages and green finance are adversely correlated. For example, a seminal work of Morgan (2013) [34] pointed out that the closer the association with the government ties, the enterprises will evade more emissions. Further, they argued that since the Government provides their associate firms protection from the law, therefore they will like to perform negatively towards the environmental responsibilities. In addition, evidence shows that the politically connected firms are more enthusiastic about poor ecological performance [9], which provides support for the negative relationship between political connections and environmental performance.

From the above-mentioned studies, it is clear that the studies have a different point of view about the green development trend and political ties. Nowadays, the governments of under-developing countries are also playing a significant role in promoting green finance. While taking parameters for the development of gree finance, governments around the world have started to take steps to downgrade pollution [33]. The Government's series of related measures include initiating green initiatives, introducing green technology, and even directly integrating environmental management into the national development planning and the national project [38]. Also, Government introduces Green GDP, and several other environmental protection policies are applied to fulfill their ecological responsibilities [29]. In this regard, it seems unlikely that the Government will indulge related firms in evading their environmental responsibility.
Zhang et al., (2019) [51] also found that after incorporating environmental protection into the official assessment system, companies with political connections have increased their environmental investment. In conclusion, from the green finance perspective, if a firm is with governmental linked even then, they have to undertake the escape environmental responsibility.

\subsection{Political connections and firm performance}

The characteristics of a firm evolve gradually from the start-up to a small business entity, and then finally to an initial public offering that turns the entity into a corporate firm with the inclusion of public shareholdings. The small business entity usually establishes by an individual or a family before becoming a corporate firm. As the family business grows, it faces new challenges at the different stages of business expansion [40], e.g., sourcing additional capital and acquiring business opportunities. The privatization of public, commercial entities is another way a firm gets linked with the political group. Given growth of a firm, a political connection provides an advantage in facing the challenges of the business growth of small firms owned by the family [46]. Therefore, the members often get involved in politics and take membership in the political parties; thus, many family firms' founders are politically connected.

The associations between firms and politicians are common phenomena in all over the world. Most of the studies exhibit that political connections positively impact firms' value, and politically connected firms have accounted for a considerable percentage of the world stock market [5; 22]. Second, close ties with the government can control market failure to avoid ideological discrimination but privatized firms cannot handle all these tasks [39]. Many founders of the firms are politically connected, and they like to appoint the second generation as directors [36], so this thing will be economically significant and reduce the transfer cost. Different approaches prove that politically connected firms have more access to long-term financing, then nonconnected firms. There is the existence of political connections that have to impact firms' performance in India. After the rigorous study, it is safe to assume that political connection has influenced stock prices [21]. It is because of the involvement in corruption, most of the political leaders are not able to work with firms. Similarly, there is found a positive relationship between political connections and access to short-term loans [48].

The empirical studies emphasis that politically connected firms can access more efficiently easily than non-political connected firms. Political connections are known as a widespread phenomenon in all over the world. It is because the politically connected networks gain various preferential treatments like lax regulations, bank financing, and government bailouts [17]. The efficiency of firms has heavily influenced these treatments. Most studies prove that there is a significant relationship between leverage and political connections. There are positive associations between market to book ratio and leverage [22]. So, politically connected firms can enjoy high leverage compared to other firms, and it has a significant effect on firms' efficiency. To sum up, it is a significant channel to improve the firm's performance. On the other side, there is a positive as well as a negative impact on the firm s performance that is given below.

In the business world, the corporation facing several threatens regarding their survival. It is also that there is a mixed effect of political connections on corporation 
performance. In recent years, widespread political connections have generated substantial empirical literature concerning the impact of political connections on its performance [28]. Most of the studies prove that political connections are known as two sword edges as it has both positive and negative effects. In some countries, there is more threat of political extraction [6]. Therefore, firms did not keep their assets in liquid shape, and they try best to save their assets from political extractions. Most private ownership prefaces efficient resource allocation rather than political controls because political members seek extra benefits from private shareholders. In such circumstances, more connections with political members can detriment the firm's value.

\subsection{Other financial benefits of political connections}

The politically connected firms are establishing a high level of unemployment and substantial fiscal deficits in a region. In particular, the firms with more political connections make such type of strategies, which are not favorable for the development of corporations like maximization the employment level at the expenses of shareholders with more political connections make such type of strategies [45] and development of firms like maximization the employment level at the expenses of shareholders. Similarly, political members have the base focus on their political agendas rather than firms' performance [26]. In summise, with increasing PC index, the firm's value starts decreasing.

In fewer developing countries, political connections are more prevalent. It has the worst impact on foreign direct investment, known as the main determinate of progress. Therefore, it is seen that there is a negative association between political connections and firms' performance. A growing literature document that political associations provide a valuable source to firms for the nurturing of firms. Political connections are more prevalent in a well-developed financial market like the US [28], and their shareholders are seen well protected. Politically connected firms have a larger market share [24], pay low taxes [25], and have more credit access than other firms [7]. The politically connected firms in the high develop country impose their elections expenses to their shareholders. These expenses are influenced by corporate performance. In the end, it is proved that in some situations, political connections have a positive and negative impact on the corporation performance.

\section{Discussion}

The nexus between government and business is considered as the most intense public debate in this era. In the context of business, operational efficiency can be measured based on high stock returns. For all corporations, employees are known as more useful assets. It is known as a more vital part of any corporation. There is a negative association between politically connected firms and operational efficiency due to unnecessary employment [19]. Most studies demonstrated that peers could achieve their goal after enhancing the profit efficiency. The crucial target of the firm is to maximize profit. Firm efficiency is one of the effective channels through which a corporation can become more efficient. There is various evidence that the government can increase the firm's profit efficiency by providing preferential regulations, additional contracts, and additional benefits like tax advantages. These are the factors that have a key role in enhancing firms' profit efficiency [1].

There is ample evidence which proves that politically connected firms have a lot of agency problem due to their influence. It hurts efficiency because, in such firms, there is a lack of motivation between managers and employees [37]. In the corporate world, for the nurturing of firms, there is a need to enhance the cost-efficiency. These are some plausible evidence that proves that cost efficiency has a crucial role in promoting the entities. Politically connected firms have lowcost efficiency as compared to others because they incur high labor costs.

In the business world, operational efficiency can be measured based on more output. There is a need for the right combination of employees, new technology, and processes to improve operational efficiency. To boost the performance of the company, the management should be skill and efficient. Political members have the worst impact on the operation efficiency of peers. The reason beyond that they are busy enhancing their income rather than the firm's operations. There is a lack of internal communications in non-politically connected firms due to their influence [43].

They do not give incentives to competent persons while giving incentives for employees who have a close relationship with the government. It is because of the low morale of employees firms efficiency move towards downward. For the development of business, there is a need for a positive culture. There is a conflict between political members and other employees due to their behavior. They do not take an interest in the documents activates and maintain the stander of the corporation because they are engaged in their political agenda. Politically connected firms exert a negative impact on operational efficiency because they incur a large amount of labor cost as compared to other peers [47]. Due to political instability, there are more chances of errors in calculations; therefore, these connections harm firm efficiency [11]. Most of the studies examine that strength of political members has influenced the firm efficiency.

Political allies are more confidence regarding take the decision about firms rather than other firms. They can make resource allocation decisions in a very smooth way. It has a positive impact on the efficiency of firms. Multiple political connections hurt corporate performance. Often, these connections give the indicator of financial fragility. They produce products on the desire of politicians, not based on customers' desires. Therefore, it has the worst influence on the growth of firms. All this evidence shows that it hurts the performance of firms. To sum up, all this evidence proves that these associations hurt the operational efficiency of firms.

Most studies demonstrated that peers could achieve their goals after enhancing profit. The crucial target of the firm is to maximize profit. Profit enhancement is known as one of the effective channels through which a corporation can become more efficient. Politically connected firms have high profits due to their external links. Politically connected firms are more likely involved in enhancing the profit of firms, including adequate resources and subside. In a competitive market, a politician can beat their rivals due to their influence. In a developed country like China, its leaders provide plenty of capital, funds, and foreign investments. It is well recounted that political connections are indicators for investors. Due to government backup, investors want to 
invest a huge amount in such firms. In this way, they are engaged to expand the profitability of firms. So, these shreds of evidence prove that political links have a significant impact on efficiency.

The influential leader refers to evaluating the corporation's efficiency to determine the performance in the market. Most firms use this efficiency to measure the benefits, costs, and analysis of the different investment projects. In these Asian countries, the company can decide which project is more useful for further investment. In the corporate world, for the nurturing of firms, there is a need to enhance efficiency.

These are some plausible evidence that proves that cost efficiency has a crucial role in promoting the entities. Political links are potential benefits to improve the cost efficiency of a corporation. Mostly, politically firms get more market share and survive in a large market due to better production. These firms are distinguishing based on their cost-efficiency. In the competitive market, politically connected firms are more pronounced due to their high production level. They provide various edges of their corporations, including the latest technology, skill employees, effective strategy, and state resources. Political aliens can make the law that low wage rate in all the corporations. So, all this evidence proves that political connections exert a positive impact on firm performance.

Efficiency can be measured based on the revenue of the firms. It is the way to measure firm performance because it indicates the suitable utilization of all resources and enhances the profit. In the corporate world, numerous studies frequently discussed the impact of efficiency on Asian countries' performance. It has a vital role in the stability and effectiveness of all the entities. There is a need for motivation between managers and workers to increase the production level. Most of the firms face the agency problem, and it creates impediments to their growth. The political connection is caused by the separation of ownership like principle and agent. In companies, the principle-agent problem creates organizational slack, and managers take a decision for their own benefits, such as hire spare staff to do their own work [23]. To enhance efficiency, there is a need to remove the conflict between managers and employees, and it is vital to incentives for better results. Politically connected firms exacerbate agency problems due to their influence, which harms firms' efficiency.

\section{Conclusion}

There are mixed evidence that proves that political associations have both positive and negative impact on firms' performance and green finance. It is a challenging task to arbitrate between the advantages and costs of these connections. There are various consequences in prior studies that prove that it positively impacts a firm's performance, including tax exemptions, utilization of state resources and power, and gain preferential access of leverage and acquisition of the tremendous amount of market share [19]. To summarize, politically connected boards are known as substantial elements for generating resources. In-depth analysis, it is the speculative tool to boost the progress of firms. These allies have the main role in nurturing the corporations. Such sorts of peers do not face capital security due to their links. These associations are prevalent for corporation performance.

On the other hand, some studies prohibit that political connections harm the firms' environmental performance because the managerial cost is high rather than benefits. Some other factors like corruption, low morale of employees, rent-seeking benefits, and overinvestment negatively influences the firm's environmental performance [32]. Finally, all these evidence prove that political connections have both positive and negative impact on corporate performance.

\section{Reference}

[1] Agrawal A, Chadha S. Corporate governance and accounting scandals. The Journal of Law and Economics. 2005 Oct;48(2):371-406.

[2] Ang JS, Ding DK, Thong TY. Political Connection and Firm Value. Asian Development Review, Vol. 30 (2), pp. 131-166.

[3] Barney J. Firm resources and sustained competitive advantage. Journal of management. 1991 Mar;17(1):99-120.

[4] Boubakri N, Cosset JC, Saffar W. The Impact of Political Connections on Firms'operating Performance and Financing Decisions. Journal of Financial Research. 2012 Sep;35(3):397423.

[5] Boubakri N, Guedhami O, Mishra D, Saffar W. Political connections and the cost of equity capital. Journal of corporate finance. 2012 Jun 1;18(3):541-59.

[6] Caprio L, Faccio M, McConnell JJ. Sheltering corporate assets from political extraction. The Journal of Law, Economics, \& Organization. 2013 Apr 1;29(2):332-54

[7] Chan KS, Dang VQ, Yan IK. Chinese firms' political connection, ownership, and financing constraints. Economics Letters. 2012 May 1;115(2):164-7.

[8] Chaney PK, Faccio M, Parsley D. The quality of accounting information in politically connected firms. Journal of accounting and Economics. 2011 Feb 1;51(1-2):58-76.

[9] Cho CH, Patten DM, Roberts RW. Corporate political strategy: An examination of the relation between political expenditures, environmental performance, and environmental disclosure. Journal of Business Ethics. 2006 Aug 1;67(2):139-54.

[10]Coulomb R, Sangnier M. The impact of political majorities on firm value: Do electoral promises or friendship connections matter?. Journal of Public Economics. 2014 Jul 1;115:158-70.

[11]Cuñat V, Gine M, Guadalupe M. The vote is cast: The effect of corporate governance on shareholder value. The journal of finance. 2012 Oct;67(5):1943-77.

[12]David M, Sinclair-Desgagné B. Pollution abatement subsidies and the eco-industry. Environmental and Resource Economics. 2010 Feb 1;45(2):271-82.

[13]Dieleman M, Boddewyn JJ. Using organization structure to buffer political ties in emerging markets: A case study Organization Studies. 2012 Jan;33(1):71-95

[14]Ding S, Jia C, Wu Z, Zhang X. Executive political connections and firm performance: Comparative evidence from privatelycontrolled and state-owned enterprises. International Review of Financial Analysis. 2014 Dec 1;36:153-67.

[15]Ding Y, Zhang H, Zhang J. Private vs state ownership and earnings management: evidence from Chinese listed companies. Corporate Governance: An International Review. 2007 Mar;15(2):223-38.

[16]Faccio M. Politically connected firms. American economic review. 2006 Mar;96(1):369-86

[17]Faccio M, Masulis RW, McConnell JJ. Political connections and corporate bailouts. The Journal of Finance. 2006 Dec;61(6):2597-635

[18]Fan JP, Wong TJ, Zhang T. Politically connected CEOs, corporate governance, and Post-IPO performance of China's newly partially privatized firms. Journal of financial economics. 2007 May 1;84(2):330-57.

[19]Fisman R. Estimating the value of political connections. American economic review. 2001 Sep;91(4):1095-102.

[20] Gabler CB, Panagopoulos N, Vlachos PA, Rapp A. Developing an environmentally sustainable business plan: An international B2B case study. Corporate Social Responsibility and Environmental Management. 2017 Jul;24(4):261-72

[21] Goldman E, Rocholl J, So J. Do politically connected boards 
affect firm value?. The Review of Financial Studies. 2009 Jun $1 ; 22(6): 2331-60$.

[22] Harford J, Klasa S, Walcott N. Do firms have leverage targets? Evidence from acquisitions. Journal of Financial Economics. 2009 Jul 1;93(1):1-4.

[23]Jensen MC. Agency costs of free cash flow, corporate finance, and takeovers. The American economic review. 1986 May $1 ; 76(2): 323-9$

[24] Khwaja AI, Mian A. Do lenders favor politically connected firms? Rent provision in an emerging financial market. The Quarterly Journal of Economics. 2005 Nov 1;120(4):1371-411.

[25] Kim C, Zhang L. Corporate political connections and tax aggressiveness. Contemporary Accounting Research. 2016 Mar;33(1):78-114.

[26]Larcker DF, Tayan B. Director networks: Good for the director, good for shareholders. Rock Center for Corporate Governance at Stanford University Closer Look Series: Topics, Issues and Controversies in Corporate Governance No. CGRP-08. 2010 Aug 5.

[27]Lee KH, Cin BC, Lee EY. Environmental responsibility and firm performance: the application of an environmental, social and governance model. Business Strategy and the Environment. 2016 Jan;25(1):40-53.

[28]Li H, Meng L, Wang Q, Zhou LA. Political connections, financing and firm performance: Evidence from Chinese private firms. Journal of development economics. 2008 Oct $1 ; 87(2): 283-99$.

[29] Li W, Higgins P. Controlling local environmental performance: An analysis of three national environmental management programs in the context of regional disparities in China. Journal of Contemporary China. 2013 May 1;22(81):409-27.

[30]Lin H, Zeng SX, Ma HY, Chen HQ. How political connections affect corporate environmental performance: The mediating role of green subsidies. Human and Ecological Risk Assessment: An International Journal. 2015 Nov 17;21(8):2192-212.

[31]Lin $\mathrm{H}$, Zeng $\mathrm{S}$, Ma $\mathrm{H}$, Chen $\mathrm{H}$. Does commitment to environmental self-regulation matter? An empirical examination from China. Management Decision. 2015 Jun 15

[32]Ling L, Zhou X, Liang Q, Song P, Zeng H. Political connections, overinvestments and firm performance: Evidence from Chinese listed real estate firms. Finance Research Letters. 2016 Aug 1;18:328-33.

[33] Liu Z, Li J, Zhu H, Cai Z, Wang L. Chinese firms' sustainable development-The role of future orientation, environmental commitment, and employee training. Asia Pacific Journal of Management. 2014 Mar 1;31(1):195-213.

[34] Morgan G. China's pollution woes fuelled by corruption. The Globe and Mail. 2013;13.

[35]Peng MW, Tan J, Tong TW. Ownership types and strategic groups in an emerging economy. Journal of Management studies. 2004 Nov;41(7):1105-29.

[36] Roberts PW, Klepper S, Hayward S. Founder backgrounds and the evolution of firm size. Industrial and Corporate Change. 2011 Dec 1;20(6):1515-38.

[37] Saeed A, Belghitar Y, Clark E. Political connections and firm operational efficiencies: evidence from a developing country. Review of Managerial Science. 2017 Jan 1;11(1):191-224.

[38] Saifullah MK, Kari FB, Ali MA. Linkage between public policy, green technology and green products on environmental awareness in the urban Kuala Lumpur, Malaysia. The Journal of Asian Finance, Economics and Business (JAFEB). 2017 May $31 ; 4(2): 45-53$.

[39] Salamon LM. Of market failure, voluntary failure, and thirdparty government: Toward a theory of government-nonprofit relations in the modern welfare state. Journal of voluntary action research. 1987 Jan;16(1-2):29-49.

[40] Scott M, Bruce R. Five stages of growth in small business. Long range planning. 1987 Jun 1;20(3):45-52.

[41] Sheng S, Zhou KZ, Li JJ. The effects of business and political ties on firm performance: Evidence from China. Journal of Marketing. 2011 Jan;75(1):1-5.
[42] Sun P, Mellahi K, Wright M. The contingent value of corporate political ties. Academy of Management Perspectives. 2012 Aug;26(3):68-82.

[43] Uwaoma I, Ordu PA. The Impact Of Internal Controls On Financial Management: A Case Of Production Companies In Nigeria. International Journal of Economics, Commerce and Management. 2015 Dec;3(12).

[44] Wang K, Zhang HM, Tsai SB, Wu LD, Xue KK, Fan HJ, Zhou J, Chen Q. Does a Board Chairman's Political Connection Affect Green Investment?-From a Sustainable Perspective. Sustainability. 2018 Mar;10(3):582.

[45] Wang L, Lin PT. Who benefits from political connections? Minority investors or controlling shareholders. Asia-Pacific Journal of Accounting \& Economics. 2017 Apr 3;24(1-2):1-22.

[46] Xu N, Xu X, Yuan Q. Political connections, financing friction, and corporate investment: Evidence from Chinese listed family firms. European Financial Management. 2013 Sep;19(4):675702.

[47]Xue M, Harker PT. Customer efficiency: Concept and its impact on e-business management. Journal of Service Research. 2002 May;4(4):253-67.

[48] Yang D, Lu Z, Luo D. Political connections, media monitoring and long-term loans. China Journal of Accounting Research. 2014 Sep 1;7(3):165-77.

[49] Yu X, Zhang P, Zheng Y. Corporate governance, political connections, and intra-industry effects: Evidence from corporate scandals in China. Financial Management. 2015 Mar;44(1):4980.

[50]Zhang C. Political connections and corporate environmental responsibility: Adopting or escaping?. Energy Economics. 2017 Oct 1;68:539-47.

[51]Zhang L, Ye F, Yang L, Zhou G. Impact of Political Connections on Corporate Environmental Performance: From a Green Development Perspective. Sustainability. 2019 Jan;11(5):1317. 